\title{
ANALISIS PERSEPSI PETANI TERHADAP PROGRAM KAWASAN RUMAH PANGAN LESTARI DI KAMPUNG DOSAI DISTRIK SENTANI BARAT KABUPATEN JAYAPURA PROVINSI PAPUA
}

\author{
*Edison Ayakeding, Keppi Sukesi, Yayuk Yuliati \\ Fakultas Pertanian, Universitas Brawijaya, Malang \\ *Corresponding author: edisonayakeding1977@gmail.com
}

\begin{abstract}
Papua is one of the provinces in Indonesia which has the characteristics of a different man in the business of fulfilling the needs of the family. The program of the Ministry of agriculture through community empowerment efforts to optimize the benefits of the grounds as a source of food family. Jayapura Regency is one of the areas that are also experiencing food security problems. Adequacy of food and nutrition is one of the most influential factors in producing quality human resources. The purpose of this research is to analyze the perceptions and the factors that influence the perception of farmers against the program Area Homes Preserved Food. Research conducted in the Western County of Sentani Dosai district of Jayapura of Papua by engaging 25 respondents who implement programs KRPL in 2013. The technique of collecting data through observation method, Now as well as granting interviews specifically. Type a descriptive quantitative data. The measurement of perception of farmers using likert scale gauge. The results of the measurements indicate that the level of perception of farmers against very low KRPL program. Testing free variables using multiple linear regression analysis. The results of the analysis showed that the fulfillment of the needs and knowledge of the real effect, While the individual characteristics, experience factor farmer KRPL and support agencies have no effect on real. The value of $R$-sq (adj) indicates the magnitude of the influence of variables against the perception that is free of $46.83 \%$, While the $53.17 \%$ influenced by other factors outside of this research.
\end{abstract}

Keywords: Program KRPL, perception of farmer, the family food and nutrition

\begin{abstract}
Abstrak: Papua merupakan salah satu provinsi di Indonesia yang memiliki karakteristik manusia yang berbeda-beda dalam usaha pemenuhan kebutuhan keluarga. Program Kementerian Pertanian melalui upaya pemberdayaan masyarakat untuk mengoptimalkan manfaat pekarangan sebagai sumber pangan keluarga. Kabupaten Jayapura merupakan salah satu daerah yang juga mengalami masalah ketahanan pangan. Kecukupan pangan dan gizi merupakan salah satu faktor yang berpengaruh dalam menghasilkan sumber daya manusia yang berkualitas. Tujuan penelitian ini adalah menganalisis persepsi dan faktor-faktor yang mempengaruhi persepsi petani terhadap program Kawasan Rumah Pangan Lestari. Penelitian dilakukan di Kampung Dosai Distrik Sentani Barat Kabupaten Jayapura Papua dengan melibatkan 25 responden yang melaksanakan program KRPL pada tahun 2013. Teknik Pengumpulan data melalui metode observasi, pemberian angket serta wawancara secara spesifik. Jenis data deskriptif kuantitatif. Pengukuran persepsi petani menggunakan alat ukur skala likert. Hasil pengukuran menunjukkan bahwa tingkat persepsi petani terhadap program KRPL sangat rendah. Pengujian variabel bebas menggunakan alat analisis regresi linier berganda. Hasil analisis menunjukkan bahwa faktor pemenuhan kebutuhan dan pengetahuan berpengaruh nyata sedangkan faktor karakteristik individu, pengalaman usaha tani KRPL dan dukungan instansi tidak berpengaruh nyata. Nilai R-sq(adj) menunjukan besarnya pengaruh variabel
\end{abstract}


Edison A., Keppi S., Yayuk Y.: Analisis Persepsi Petani Terhadap...

bebas terhadap persepsi yaitu sebesar $46,83 \%$, sedangakan $53,17 \%$ dipengaruhi faktorfaktor lain diluar dari pada penelitian ini.

Kata Kunci: Program KRPL, Persepsi Petani, Pangan dan Gizi Keluarga

\section{PENDAHULUAN}

Proses keberhasilan pembangunan sangat dipengaruhi oleh kualitas sumber daya manusia (SDM) yang baik. Indikator pemanfaatan pangan adalah apabila seluruh rumah tangga dapat mengkonsumsi pangan yang bergizi, beragam, dan berimbang sehingga dapat mendukung seseorang untuk hidup sehat dan produktif (Suryana, 2008). Kecukupan pangan dan gizi merupakan salah satu faktor yang berpengaruh dalam menghasilkan sumber daya manusia yang berkualitas apabila kebutuhan yang dimaksud dapat tercukupi karena ketersedian pangan yang cukup bagi setiap individu merupakan hal yang sangat penting (Kementerian Pertanian, 2010). Penduduk Indonesia termasuk dalam kategori rawan pangan yang relatif tinggi jumlahnya yaitu 128,56 juta jiwa atau 51,14 persen dari jumlah penduduk Indonesia di tahun 2014, hal tersebut harus segera ditanggulangi dengan melakukan peningkatan keanekaragaman pangan. Penganekaragaman konsumsi pangan merupakan upaya untuk memantapkan atau membudayakan pola konsumsi pangan yang beragam, bergizi seimbang dan aman dalam jumlah dan komposisi yang cukup guna memenuhi kebutuhan gizi untuk mendukung hidup sehat, aktif dan produktif.

Papua merupakan salah satu provinsi di Indonesia yang juga mengalami masalah ketahanan pangan. Hasil wawancara dengan sekertaris Kantor Ketahanan Pangan Kabupaten Jayapura dijelaskan bahwa Jayapura yang merupakan salah satu kabupaten di Provinsi Papua yang sampai saat ini masih juga mengalami masalah ketahanan pangan. Dalam upaya mengatasi permasalahan tersebut, Kantor Ketahanan Pangan kabupaten Jayapura telah mengimplementasikan beberapa program dalam rangka kecukupan pangan melalui program P2KP dengan memanfaatkan lahan pekarangan yang disebut sebagai Program Kawasan Rumah Pangan Lestari (KRPL) melalui upaya pemberdayaan masyarakat untuk mengoptimalkan manfaat pekarangan sebagai sumber pangan keluarga. Upaya ini dilakukan dengan membudidayakan berbagai jenis tanaman sesuai kebutuhan keluarga seperti aneka sayuran, buah-buahan, umbi-umbiaan serta budidaya ternak dan ikan sebagai tambahan untuk ketersediaan sumber karbohidrat, protein, lemak, mineral dan vitamin bagi keluarga. Sasaran kegiatan Program KRPL adalah rumah tangga yang beranggotakan minimal 30 rumah tangga yang berdomisili berdekatan dalam satu Kampung yang membentuk suatu kawasan. Tujuan pelaksanaan program KRPL adalah guna mencukupi ketersediaan pangan dan gizi di tingkat rumah tangga.

Persepsi petani merupakan bagian yang tak terpisahkan dalam menilai arti dan manfaat dari suatu obyek yang diamati dan dilakukan. Setiap orang mengintepretasikan kondisi yang sama dengan cara yang berbeda dan setiap orang memiliki ekspektasi yang berbeda pula terhadap situasi yang sama (Rotter 1954, dalam Mearn, 2010), Oleh karena itu persepsi individu yang satu dengan individu yang lainnya terhadap Program KRPL akan saling berbeda. Hal ini yang menyebabkan mengapa seseorang tertarik pada suatu obyek, namun yang lainnya sebaliknya bertolak belakang dengan obyek tersebut. Pada kenyataannya sebagian besar sikap, tingkah laku dan penyesuaian ditentukan oleh persepsinya. Jika persepsi masyarakat terhadap program tersebut baik, maka program diharapkan dapat berjalan dengan baik dan dapat dilaksanakan secara terus menerus dan berkelanjutan.

Papua, memiliki karakteristik manusia yang berbeda-beda dalam usaha memenuhi kebutuhan pangan individu dan keluarga. Pola usahatani masyarakat di Papua pada umumnya masih bersifat tradisional di lihat dari aspek budidaya maupun pascapanennya (Rauf dan Lestari, 2009), sebagian masyarakat Papua dalam melakukan usaha pertanian dalam mencukupi kebutuhan hidupnya masih melakukan usahatani tradisional dengan berkebun dan kebanyakan mengusahakan komoditas pangan seperti ubi jalar, ubi kayu, keladi, talas, umbi-umbian lokal lainnya dan sagu serta didukung pula ketersediaan 
sumberdaya alam yang ada namun dengan demikian hal itu hanya sebatas mencukupi kebutuhan hidup keluarga khususnya kebutuhan pangan. Guna meningkatkan kecukupan pangan dan gizi keluarga yang lebih baik maka pemerintah mencanangkan program pemanfaatan kawasan pangan (P2KP) yang diterapkan melalui konsep KRPL. Papua merupakan salah satu daerah pencanangan program kawasan rumah pangan lestari yang tersebar di beberapa Kabupaten dan Kota, salah satu penempatan program kawasan rumah pangan lestari di Kabupaten Jayapura tepatnya di Kampung Dosai yang dilaksanakan oleh 25 kepala keluarga yang berdomisili saling berdekatan yang membentuk suatu kawasan yang selanjutnya disebut sebagai kawasan rumah pangan lestari, namun dengan berjalannya waktu maka pelaksanaan program kawasan rumah pangan lestari tidak berjalan dengan baik dan munculnya kejenuhan pada petani dalam mengusahakan pertanian pola pekarangan.

Berdasarkan permasalahan yang belum diketahui penyebabnya maka Individu diharapkan dapat memberikan penilaian terhadap suatu obyek yang dapat bersifat positif atau negatif, senang atau tidak senang, mau atau tidak mau dan sebagainya. Dengan adanya persepsi maka akan terbentuk sikap, yaitu suatu kecenderungan yang stabil untuk berlaku atau bertindak secara tertentu di dalam situasi yang tertentu pula (Polak, 1976). Hal tersebut menunjukkan bahwa persepsi seseorang akan turut menentukan bagaimana bentuk nyata penerapan program KRPL di lapangan oleh orang tersebut atau dengan kata lain persepsi dari petani peserta KRPL akan menentukan keragaan dari pelaksanaan program KRPL. Oleh karena itu, perlu dilakukan penelitian mengenai persepsi petani terhadap Program KRPL serta keragaan KRPL di Kampung Dosai, Distrik Sentani Barat Kabupaten Jayapura.

\section{METODE PENELITIAN}

Jenis penelitian yang dilakukan yaitu deskriptif kuantitatif, penelitian ini menggunakan metode survey, pendekatan secara langsung kepada kelompok tani dan melakukan pengamatan di lapangan sekaligus memberikan kuesioner. Variabel X dalam penelitian ini adalah faktor- faktor yang mempengaruhi persepsi petani terhadap pelaksanaan program KRPL sedangkan variabel $\mathrm{Y}$ dalam penelitian ini adalah persepsi petani terhadap Program Kawasan Rumah Pangan Lestari (KRPL). Penelitian ini dilaksanakan di Kelompok KRPL Kampung Dosai, Distrik Sentani Barat, Kabupaten Jayapura. Lokasi penelitian ditentukan secara purposive/sengaja karena berdasarkan pada penempatan program Kawasan Rumah Pangan Lestari dan keadaan eksistensi program Kawasan Rumah Pangan Lestari di Kampung Dosai.

Penelitian ini dilakukan dengan menggunakan pendekatan kuantitatif yaitu bentuk pendekatan yang mengacu dari suatu pengalaman dilapangan dan dikembangkan selanjutnya menjadi permasalahan guna dilakukan penelitian serta mencari solusi pemecahan masalahnya. Pendekatan kuantitatif merupakan metode-metode untuk menguji teori-teori tertentu dengan cara meneliti hubungan antar variabel (Creswel, 2015).

Populasi adalah wilayah generalisasi yang terdiri atas objek/subjek yang mempunyai kuantitas dan karakteristik tertentu yang ditetapkan oleh peneliti untuk dipelajari dan kemudian ditarik kesimpulannya (Sugiyono, 2008), sedangkan dalam menemtukan populasi yang kecil maka biasanya pengambilan sampel diambil sebagian besar atau secara keseluruhan (Levis, 2013). Berdasarkan pendapat tersebut maka penetapan populasi dalam penelitian ini dilakukan secara sensus yaitu dengan pengambilan total keseluruhan dari 25 kepala keluarga yang melaksanakan program KRPL di Kampung Dosai.

Teknik pengambilan sampel dalam penelitian ini adalah dilakukan melalui sensus terhadap anggota kelompok KRPL. Menentukan ukuran sampel bergantung pada tingkat ketepatan dari sampel populasi dimana populasi tersebut mampu menggambarkan kualitas dan karakteristik dari total populasi (Levis, 2013). Penentuan sample dengan melakukan sensus yang dimaksud adalah seluruh kepala keluarga yang telah melaksanakan program Kawasan Rumah Pangan Lestari di Kampung Dosai Distrik Sentani Barat.

Jenis dan sumber data yang digunakan dalam penelitian ini yaitu : Data primer yaitu data yang di peroleh secara langsung dari lokasi 
penelitian melalui observasi dilakukan dengan melaksanakan pengukuran secara langsung terhadap subyek penelitian, pengambilan data dilakukan dengan mewawancarai responden dan pembagian kuisioner terhadap responden serta data Sekunder yaitu data yang di peroleh dari Kantor Dinas Ketahanan Pangan Kabupaten Jayapura, Badan Pusat Statistik (BPS) Kabupaten Jayapura dan Kantor Pemerintahan Kampung Dosai serta data-data penunjang yang berhubungan dengan penelitian ini berupa literatur atau referensi.

Teknik Pengumpulan data melalui metode observasi, yaitu dengan melakukan pengamatan langsung terhadap obyek yang akan diamati, memberikan kuisioner dan melakukan wawancara secara mendalam serta melakukan pengumpulan data sekunder. Data yang terkumpulkan meliputi data primer yaitu karakteristik individu, pemenuhan kebutuhan, pengalaman usahatani, pengetahuan terhadap program KRPL dan dukungan instansi serta data sekunder yang meliputi topografi lokasi penelitian dan keadaan penduduk di Kampung Dosai.

Analisis data dilakukan secara deskriftif kuantitatif untuk menguji hipotesis mengenai faktor-faktor yang mempengaruhi persepsi petani terhadap program KRPL. Data dianalisis mengunakan analisis regresi linear berganda. Regresi linier berganda didasarkan pada hubungan fungsional ataupun kausal beberapa variabel independen dengan satu variabel dependen (Sugiyono, 2008). Kegunaan analisis regresi linier berganda merupakan alat untuk mengukur besarnya pengaruh variabel bebas terhadap variabel tergantung dan memprediksi variabel tergantung dengan menggunakan variabel bebas (Sarwono, 2006). Untuk mengetahui apakah faktor-faktor karakteristik individu, pemenuhan kebutuhan, pengalaman usahatani, pengetahuan terhadap program KRPL dan dukungan instansi terdapat pengaruh terhadap persepsi petani pada program KRPL di Kampung Dosai Distrik Sentani Barat Kabupaten Jayapura, maka dilakukan uji hipotesis dengan model persamaan Regresi Linear berganda seperti berikut ini :

$Y=a+b_{1} X_{1}+b_{2} X_{2}+b_{3} X_{3}+b_{4} X_{4}+b_{5} X_{5}+e$

Keterangan :

$\mathrm{Y}=$ Persepsi petani terhadap Program KRPL $\mathrm{a}=$ Konstanta

$\mathrm{x} 1=$ Karakteristik Responden

$\mathrm{x} 2=$ Pemenuhan Kebutuhan

$\mathrm{x} 3=$ Pengalaman

$\mathrm{x} 4=$ Pengetahuan

$\mathrm{x} 5=$ Dukungan Instansi Terkait

\section{HASIL DAN PEMBAHASAN}

\section{Karakteristik Individu Responden}

Karakteristik responden yang digunakan dalam penelitian ini adalah seluruh anggota kelompok KRPL di Kampung Dosai yang berjumlah sebanyak 25 kepala keluarga dengan keberadaan karakteristik yang berbeda-beda. Perilaku sosial petani terikat pada pribadi masing-masing individu dalam kelompok, dengan demikian maka karakteristik individu yang digunakan dalam penelitian ini adalah usia, pendidikan, status kepemilikan lahan, lama berusahatani, penghasilan perbulan dari hasil usaha KRPL.

\section{Usia Responden}

Faktor intern dari individu yang berpengaruh terhadap proses kegiatan manusia dalam dunia kerja guna pemenuhan kebutuhan hidupnya yaitu faktor usia. Dalam suatu usaha pertanian yaitu dilihat dengan makin muda usia petani biasanya memiliki semangat yang tinggi dan memiliki rasa ingin tahu tentang sesuatu yang baru atau sesuatu yang belum diketahuinya (Soekartawi, 2005). Oleh sebab itu usia merupakan faktor yang paling penting dari karakteristik responden yang diamati. Usia dari responden dikategorikan ke dalam empat kategori yaitu Sangat produktif (21-35 tahun), usia produktif (36-50 tahun), usia kurang produktif (51-65 tahun) dan usia tidak produktif ( $>66$ tahun)

Tabel 1. Persentase Jumlah Petani Responden sesuai

\begin{tabular}{clcc}
\multicolumn{2}{c}{ Usia } & & \\
$\begin{array}{c}\text { Usia } \\
\text { (Tahun) }\end{array}$ & Kategori & $\begin{array}{c}\text { Jumlah } \\
\text { Responden }\end{array}$ & $\begin{array}{c}\text { Persentasi } \\
(\%)\end{array}$ \\
\hline \multirow{2}{*}{$21-35$} & Sangat & & \\
$36-50$ & Produktif & 8 & 32 \\
& $\begin{array}{l}\text { Produktif } \\
\text { Kurang }\end{array}$ & 11 & 44 \\
& $\begin{array}{l}\text { Kroduktif } \\
\text { Tidak }\end{array}$ & 6 & 24 \\
& $\begin{array}{l}\text { Tidak } \\
\text { Produktif }\end{array}$ & 0 & 0 \\
\hline Total & & 25 & 100 \\
\hline
\end{tabular}

Sumber : Data primer diolah 
Berdasarkan Tabel 1. Dapat dilihat bahwa usia responden dengan persentase tertinggi berada pada usia 36-50 tahun atau 44 persen dengan kategori produktif, selanjutnya usia sangat produktif menempati posisi kedua dengan nilai persentasinya sebesar 32 persen dan diikuti dengan usia responden yang kurang produktif yaitu sebesar 24 persen. Hasil persentase diatas menuunjukkan bahwa petani yang menerima dan mengusahakan kawasan rumah pangan lestari didominasi oleh orang tua. Hal ini disebabkan oleh banyak usia muda yang tidak mau terlibat kedalam usahatani dibidang pertanian.

\section{Pendidikan Responden}

Pendidikan merupakan hal yang tidak kalah pentingnya agar petani dapat mengakses informasi dan juga dapat mengadopsi teknologi secara baik. Pendidikan responden ditetapkan kedalam empat kategori yaitu tidak tamat SD atau tamat SD, tamat SMP/sederajat, tamat SMU/sederajat dan pendidikan yang tertinggi adalah tamat perguruan tinggi/sederajat.

Tabel 2. Tingkat Pendidikan Responden

\begin{tabular}{|c|c|c|}
\hline Tingkat pendidikan & $\begin{array}{c}\text { Jumlah } \\
\text { Responden } \\
\end{array}$ & $\begin{array}{c}\text { Persentase } \\
(\%)\end{array}$ \\
\hline $\begin{array}{l}\text { Sangat rendah (tidak } \\
\text { Tamat SD/tamat SD) }\end{array}$ & 4 & 16 \\
\hline $\begin{array}{l}\text { Rendah ( Tamat SMP/ } \\
\text { Sederajat) }\end{array}$ & 14 & 56 \\
\hline $\begin{array}{l}\text { Cukup tinggi ( Tamat } \\
\text { SMA/sederajat) }\end{array}$ & 2 & 8 \\
\hline $\begin{array}{l}\text { Tinggi ( Tamat Perguruan } \\
\text { tinggi/ sederajat }\end{array}$ & 5 & 20 \\
\hline Total & 25 & 100 \\
\hline
\end{tabular}

Jumlah petani responden menurut pendidikan terendah hingga tertinggi dapat dilihat pada Tabel 2. Tingkat pendidikan petani responden yang melaksanakan program kawasan rumah pangan lestari (KRPL) adalah tamat SMP dengan nilai persentasi sebesar 56 persen dengan kategori rendah, dengan demikian maka dapat dikatakan bahwa petani responden dengan kategori rendah. Hal ini dapat menyebabkan tidak tersalurnya atau terdesiminasi informasi dan inovasi teknologi dengan baik.

\section{Lahan dan Status Kepemilikan}

Lahan merupakan tempat dimana orang melakukan aktivitas usaha dengan berbagai bidang. Dalam melakukan kegiatan usahatani dipekarangan seringkali terbentur dengan masalah hak kepemilikannya sehingga petani yang tidak memiliki lahan biasanya dilakukan dengan menyewa atau mengelola dengan perjanjian bagi hasil. Untuk melihat status kepemilikan lahan dalam kegiatan program kawasan rumah pangan lestari dapat disajikan pada Tabel 3.

Tabel 3. Status Kepemilikan Lahan

\begin{tabular}{|c|c|c|}
\hline Status Lahan & $\begin{array}{c}\text { Jumlah } \\
\text { Responden }\end{array}$ & $\begin{array}{l}\text { Persentasi } \\
(\%)\end{array}$ \\
\hline Milik Sendiri & 21 & 84 \\
\hline Sewa & 2 & 8 \\
\hline $\begin{array}{l}\text { Garap/Sistim Bagi } \\
\text { Hasil }\end{array}$ & 0 & 0 \\
\hline Lainnya & 2 & 8 \\
\hline Total & 25 & 100 \\
\hline
\end{tabular}

Sumber : Data primer hasil olah

Berdasarkan Tabel 3. dapat digambarkan bahwa jumlah terbesar pada status kepemilikan lahan yaitu lahan milik sendiri dengan persentase sebesar 84 persen, selanjutnya lahan yang digunakan dengan menyewa adalah sebesar 8 persen, sementara lahan lainnya yaitu lahan yang digunakan dengan sistim menumpang tinggal dengan persentase 8 persen. Dengan persentase tertinggi adalah lahan milik sendiri maka ini, hal ini merupakan peluang dalam melakukan usaha pola pekarangan sangat baik dalam pemenuhan kebutuhan keluarga.

\section{Penghasilan Perbulan berdasarkan Usahatani KRPL}

Pendapatan seseorang tentu memiliki peran yang penting dimana seseorang dalam memuaskan kebutuhannya yang berhubungan dengan keputusan pembelian yang akan dilakukan. Responden berdasarkan pendapatan disajikan pada tabel berikut:

Tabel 4. Penghasilan Perbulan dari Usaha KRPL

\begin{tabular}{ccc}
$\begin{array}{c}\text { Penghasilan } \\
\text { perbulan }\end{array}$ & $\begin{array}{c}\text { Jumlah } \\
\text { Responden }\end{array}$ & $\begin{array}{c}\text { Persentasi } \\
(\%)\end{array}$ \\
\hline $100.000-150.000$ & 0 & 0 \\
$160.000-200.000$ & 2 & 8 \\
$210.000-250.000$ & 3 & 12 \\
$260.000-300.000$ & 20 & 80 \\
\hline Total & 25 & 100 \\
\hline
\end{tabular}

Sumber : Data primer diolah 
Pada Tabel 4, terlihat bahwa pendapatan petani dengan mengusahakan tanaman di lahan pekarangan dapat di lihat dengan adanya nilai persentase hasil pendapatan yang sangat baik yaitu 80 persen dari total responden dengan penghasilan perbulan dalam mengusahakan KRPL berkisar antara Rp. 260.000 - 300.000, selanjutnya dengan persentase 12 persen adalah responden yang berpendapatan dengan kisaran Rp. $210.000-250.000$ dan yang berpendapatan terendah yaitu dengan nilai persentase sebesar 8 persen yang berpendapatan dibawah $\mathrm{Rp}$. 200.000 yang dapat di kategorikan sebagai penghasilan yang rendah.

\section{Persepsi Petani terhadap Program Kawasan Rumah Pangan Lestari}

Parcek dalam Walgito (2002) menyatakan bahwa proses terjadinya persepsi adalah pembentukan persepsi yang berlangsung melalui beberapa tahapan proses mulai dari menerima, menyeleksi, mengorganisasi, mengartikan, menyajikan dan memberikan reaksi kepada rangsang panca indera. Untuk melihat hasil wawancara terhadap petani sebagai responden pada program KRPL pada kasus pemanfaatan lahan pekarangan di masyarakat Kampung Dosai Distrik Sentani Barat Kabupaten Jayapura provinsi Papua. Persepsi petani pada penelitian ini tidak lepas dari karakteristik dari responden (petani) yang meliputi karakteristik individu, Tingkat pemenuhan kebutuhan, tingkat pendapatan, dan pengalaman. Sedangkan persepsi dari program KRPL masuk dalam karekteristik usahatani, yang di dalamnya terdapat manfaat KRPL, pelaksanaan KRPL, dan potensi KRPL. Pada Tabel 5 terlihat bahwa kisaran skor aspek manfaat yaitu sebesar 3,74 dengan nilai persentasi sebesar 15,56\%, pada aspek pelaksanaan program KRPL dapat dilihat bahwa angka skor lapang yang diperoleh yaitu sebesar 3,45 dengan nilai persentasi sebesar $28,71 \%$ dan aspek potensi program KRPL dengan skor lapang yaitu sebesar 3,57 dengan nilai persentasi sebesar 29,70 dengan demikian maka dapat dilihat bahwa dari ketiga aspek persepsi masyarakat Kampung Dosai terhadap program KRPL diatas dapat dikategorikan berpersepsi rendah.

\section{Hasil Analisis Regresi Linier Berganda}

Dalam dunia penelitian, analisis data merupakan salah satu bagian dari proses penelitian yang dilakukan setelah semua data yang diperlukan telah terhimpun. Hal tersebut dilakukan agar sebuah permasalahan yang berada pada suatu objek dapat terpecahkan. Keakuratan daripada sebuah alat analisis dalam sebuah penelitian merupakan penentu dalam mengambil suatu kesimpulan, oleh karena itu, kegiatan analisis data merupakan rentetan dalam proses penelitian yang tidak dapat terpisahkan. Proses pengolahan data menggunakan software Minitab 16. Selanjutnya data dianalisis menggunakan analisis regresi linier berganda untuk mengetahui pengaruh faktor-faktor terhadap persepsi petani pada program Kawasan Rumah Pangan Lestari.

Berdasarkan hasil analisis regresi linier berganda pada tabel diatas dapat digambarkan hasil persamaan regresi sebagai berikut:

$$
\begin{aligned}
\mathrm{Y}= & 9.90+0,650 \mathrm{X}_{1}+\left(-2.281 \mathrm{X}_{2}\right)+0.089 \mathrm{X}_{3}+ \\
& 0.806 \mathrm{X}_{4}+1.040 \mathrm{X}_{5}
\end{aligned}
$$

Hasil analisis regresi pada tabel diatas dapat dilihat bahwa Nilai konstanta pada persamaan regresi $(\alpha)$ bernilai positif yaitu sebesar 9,90 dan tidak berpengaruh signifikan. Variabel karakteristik individu petani berpengaruh signifikan terhadap persepsi petani dengan tingkat kepercayaan 99\%. Hal ini menunjukkan bahwa karakteristik individu akan menentukan persepsi petani. Pada umumnya petani berada pada usia produktif yang dapat dikatakan sangat berpeluang dalam melaksanakan usahatani pola pekarangan. Dilihat dari kepemilikan lahan, rata-rata petani responden memiliki lahan pekarangan yang cukup luas dengan status lahan milik sendiri.

Variabel pemenuhan kebutuhan berpengaruh negatif dan signifikan pada taraf kepercayaan 95\%. Semakin terpenuhi kebutuhan petani, maka persepsi petani terhadap program Kawasan Rumah Pangan Lestari akan menurun. Hal ini dikarenakan persepsi responden dipengaruhi adanya manfaat yang dirasakan dalam penerapan program KRPL, yaitu dapat memudahkan petani responden dalam mencukupi kebutuhan gizi keluarga. 
Edison A., Keppi S., Yayuk Y.: Analisis Persepsi Petani Terhadap...

Tabel 5 . Skor persepsi Terhadap Program KRPL di Kampung Dosai

\begin{tabular}{clcccc}
\hline \multirow{2}{*}{ No } & \multicolumn{2}{c}{ Indikator } & \multicolumn{3}{c}{ Rata-rata skor } \\
\cline { 3 - 6 } & & $\begin{array}{c}\text { Skor } \\
\text { Lapang }\end{array}$ & $\begin{array}{c}\text { Skor } \\
\text { Max }\end{array}$ & $\begin{array}{c}\text { Skor max } \\
(\%)\end{array}$ & Kategori \\
\hline 1 & Persepsi Terhadap Manfaat Program KRPL & 3,74 & 24,03 & 15,56 & Rendah \\
2 & Persepsi Terhadap Pelaksanaan Program KRPL & 3,45 & 12,03 & 28,71 & Rendah \\
3 & Persepsi Terhadap Potensi KRPL & 3,57 & 12,03 & 29,70 & Rendah \\
\hline
\end{tabular}

Sumber : Data primer diolah

Tabel 6. Hasil Analisis Regresi Berganda

\begin{tabular}{lrrrrr}
\hline \multicolumn{1}{c}{ Variabel } & Koefisien & \multicolumn{1}{c}{ SE } & t-value & P-value & VIF \\
\hline Constant & 9,90 & 8,94 & 1,11 & 0,282 & \\
Karakteristik Individu (X1) & $0,650^{*}$ & 0,334 & 1,95 & 0,067 & 1,41 \\
Pemenuhan Kebutuhan (X2) & $-2,281^{* *}$ & 0,836 & $-2,73$ & 0,013 & 1,65 \\
Pengalaman Usahatani (X3) & 0,089 & 0,646 & 0,14 & 0,892 & 2,87 \\
Pengetahuan Terhadap KRPL (X4) & $0,806^{* *}$ & 0,369 & 2,19 & 0,041 & 2,34 \\
Dukungan Instansi (X5) & $1,040^{*}$ & 0,562 & 1,85 & 0,080 & 1,83 \\
\hline F-hitung & $5.23^{* * *}$ & & & & \\
$R$-square & 0,5791 & & & & \\
Adjusted $R$-square & 0,4683 & & & &
\end{tabular}

Sumber : Analisis Data Primer, 2018

Keterangan:

*** signifikan pada taraf kepercayaan $99 \%$; ** signifikan pada taraf kepercayaan $95 \%$; * signifikan pada taraf kepercayaan $90 \%$

Pengalaman seseorang merupakan fakta empiris yang pernah dialami yang menjadi pelajaran dalam hidup yang dapat dimanfaatkan kemudian. Akan tetapi pada penelitian ini, variabel pengalaman tidak berpengaruh signifikan. Pengalaman petani responden di Kampung Dosai menunjukkan bahwa usahatani di pekarangan sudah biasa dilakukan walau masih bertani secara tradisional, meskipun masih terdapat beberapa kendala seperti keamanan dalam berusahatani dan kesadaran masyarakat dalam berusahatani dengan usahatani pola pekarangan.

Proses dalam menindaklanjuti suatu kegiatan tentu harus didukung dengan pengetahuan Pengetahuan yang merupakan informasi yang dikombinasikan berdasarkan pemahaman dan potensi untuk ditindaklanjuti, pengetahuan merupakan responsif dari indera individu yang melekat di benak seseorang dengan kemampuan prediktif berdasarkan perlakuan terhadap suatu obyek.

Variabel pengetahuan terhadap program KRPL dan pelaksanaannya berpengaruh signifikan dengan tingkat kepercayaan 95\%. Selanjutnya dapat dijelaskan bahwa teknologi dan inovasi dengan konsep pola pemanfaatan lahan pekarangan merupakan hal yang baru bagi petani responden di Kampung Dosai. Berdasarkan inovasi teknologi budidaya pertanian yang berbasis pada pemanfaatan lahan pekarangan melalui program KRPL maka muncul antusias petani responden untuk mengadopsi inovasi teknologi lebih mendalam.

Hanifah et al. (2014), mengemukakan bahwa faktor-faktor yang mempengaruhi tingkat motivasi petani dalam melakukan suatu kegiatan usahatani yaitu kurangnya pemahaman tentang kegiatan yang harus dilakukan, prosedur dan keuntungan yang akan diperoleh. Instansi atau lembaga yang berperan penunjang seperti lembaga pembiayaan, penyuluhan, lembaga pengolahan serta lembaga penelitian dan pengembangan merupakan lembaga yang juga ikut berperan dalam membantu petani dalam proses usahataninya (Yuniati et al., 2017). Terkait dengan pernyataan tersebut bahwa dalam proses pelaksanaan dan pendampingan program KRPL dikampung dosai dilaksanakan dengan baik sehingga proses pendampingan dan dukungan instansi cukup baik dirasakan oleh petani KRPL dikampung Dosai. Variabel dukungan instansi berpengaruh signifikan dengan tingkat kepercayaan $90 \%$. Hal ini dikarenakan tingkat dukungan dalam pelaksanaan program KRPL 
terkait teknologi, sarana pertanian, benih, dan pendampingan yang sudah cukup baik mempengaruhi persepsi petani.

\section{Koefisien Determinasi}

Nilai Adjusted $R$ Square dapat diinterpretasikan sama dengan $\mathrm{R}$ square namun setiap ada penambahan variabel baru akan mempengaruhi naik atau turunnya nilai Adjusted $\mathrm{R}$ Square tergantung nilai variabel bebas yang ditambahkan dengan variabel terikat. Berdasarkan nilai Adjusted $R$ Square pada tabel diatas bahwa sebesar $46,83 \%$ dapat dijelaskan oleh variabel bebas yaitu karakteristik individu (X1), tingkat pemenuhan kebutuhan (X2), pengalaman berusahatani (X3), pengetahuan (X4) dan dukungan instansi (X5), sedangkan masih terdapat $53,17 \%$ yang tidak dapat dijelaskan oleh variabel bebas maka dapat diartikan bahwa terdapat $53,17 \%$ faktor yang mempengaruhi persepsi petani di kampung Dosai dipengaruhi faktor-faktor lain diluar dari pada penelitian ini.

\section{KESIMPULAN DAN SARAN}

\section{Kesimpulan}

Variabel karakteristik individu, pemenuhan kebutuhan, pengetahuan terhadap KRPL dan dukungan instansi berpengaruh signifikan terhadap persepsi petani di kampung Dosai. Sedangkan variabel pengalaman berusahatani tidak berpengaruh nyata. Petani mengharapkan ada pendampingan teknologi yang lebih baik, sehingga petani mampu memanfaatkan lahan pekarangan dengan baik dan mampu memenuhi kebutuhan keluarga dengan konsep KRPL.

\section{Saran}

Pengetahuan petani terhadap inovasi teknologi melalui konsep KRPL belum dikuasai sepenuhnya terutama tentang teknologi pemanfaatan lahan pekarangan, maka diharapkan ada pendampingan teknologi yang lebih baik dan intens agar petani mampu mengadopsi inovasi teknologi dengan baik.

\section{DAFTAR PUSTAKA}

Creswel, J. W. 2015. Research Design. Pendekatan Kualitatif, Kuantitatif dan Mixed. Yogyakarta: Pustaka Pelajar.
Hanifah, V.W., Marsetyowati, T dan Ulpah, A. 2014. Faktor-Faktor yang Mempengaruhi Konsumsi Sayuran Rumah Tangga pada Kawasan Rumah Pangan Lestari di Provinsi Jawa Timur dan Sumatera Selatan. Jurnal Pengkajian dan Pengembangan Teknologi Pertanian, 17(2), 144-153.

Jonathan, S. 2006. Metode Penelitian Kuantitatif dan Kualitatif. Yogyakarta: Graha Ilmu.

Kementerian Pertanian. 2010. Pedoman Umum Gerakan Percepatan Penganekaragaman Konsumsi Pangan (P2KP). Retrieved from http://bkp.pertanian.go.id/ proksi-9p2kp.html.

Levis, L.R. 2013. Metode Penelitian Perilaku Petani. Maumere: Seminari Tinggi Ledalero.

Polak, M. 1976. Sosiologi Suatu Buku Pengantar Ringkas. Jakarta: Ikhtiar Baru

Rakhmat, J. 2003. Psikologi Komunikasi. Bandung: Remaja Rosdakarya.

Rauf, A. W. dan Lestari, M.S. 2009, Pemanfaatan Komoditas Pangan Lokal Sebagai sumber pangan alternatif di Papua. Jurnal Litbang Pertanian, 28(2), 54-62.

Soekartawi. 2005. Agribisnis: Teori dan Aplikasisnya. Ed. 1. Cet 8. Jakarta: Raja Grafindo Persada.

Sugiyono. 2008. Metode Penelitian Kuantitatif Kualitatif dan $R \& D$. Bandung: Alfabeta.

Suryana, A. (2008/06/17). Menelisik Ketahanan Pangan, Kebijakan Pangan, dan Swasembada Beras. Pengembangan Inovasi Pertanian, Pusat Analisis Sosial Ekonomi dan Kebijakan Pertanian. Retrieved from http://staff.unila.ac.id /bungdarwin/files/2014/04/kel-2-ketahan an- pangan.pdf. 